\title{
Hemophilia A Patients with Undetectable Mutations: Current Knowledge and Future Directions*
}

\author{
Osman El-Maarri Hans H. Brackmann Peter Hanfland Johannes Oldenburg \\ Institut für Experimentelle Hämatologie und Transfusionsmedizin, Universität Bonn, Germany
}

\section{Key Words}

Hemophilia A · F8 gene · Mutation analysis .

mRNA expression

\section{Summary}

Classical hemophilia $A(H A)$ is characterized by absence or decrease in factor VIII activity. F8 is an essential cofactor of F9 to activate F10. Most known genetic mutations that lead to HA phenotype can be traced to the F8 gene itself. However, in some cases, mutations in chaperon proteins, such as LMNA1 and MCFD2, cause a decrease in secretion of both F5 and F8 resulting in a combined F5/F8 deficiency. Moreover, mutations in the domain of von Willebrand factor (VWF) that interact with F8 cause a HA-like syndrome known as type $2 \mathrm{~N}$ (Normandy) von Willebrand disease (VWD-2N). Still, in a minority of HA cases, no mutations could be attributed to any of the genes known to be involved in the F8 pathway. In this article we will give an overview of these cases and outline future efforts needed to identify the molecular defects in such patients.

\section{Introduction}

Absence or decreased activity of the F8 protein causes hemophilia A (HA) which is characterized by the occurrence of spontaneous bleeding. Mutations in the F8 gene, located at the

*Dedicated to Prof. Dr. Peter Hanfland, Bonn, on the occasion of his 65th birthday.

\author{
Schlüsselwörter \\ Hämophilie-A · F8-Gen · Mutationsanalyse · \\ mRNA-Expression
}

\section{Zusammenfassung}

Die klassische Hämophilie-A (HA) wird durch einen vollständigen oder teilweisen Mangel an Faktor VIII-Aktivität charakterisiert. Die meisten bekannten genetischen Veränderungen, die einen HA-Phänotyp verursachen, sind im Faktor 8-Gen (F8) selbst lokalisiert. In einigen seltenen Fällen sind Mutationen in den Chaperonen LMNA1 und MCFD2, welche die Sekretion von sowohl F5 als auch F8 gewährleisten, ursächlich für einen kombinierten F5/F8-Mangel. Mutationen innerhalb des Von-WillebrandFaktors (VWF), die Domänen betreffen, welche mit dem F8 interagieren, verursachen einen HA-ähnlichen Phänotyp, bekannt als von Willebrand-Syndrom Typ 2 Normandie (VWD-2N). In einzelnen Fällen kann allerdings keinem dieser Gene eine Mutation zugeschrieben werden, welche für den beobachteten Phänotyp ursächlich ist. In diesem Artikel geben wir einen Überblick über einige dieser Fälle sowie die Strategien, die zur Charakterisierung des entsprechenden molekularen Defekts angewandt werden.

telomeric end of the long arm of the $\mathrm{X}$ chromosome, have been identified as the cause of HA. Such mutations include the intron 22 and intron 1 inversions hot spots, point mutations (nonsense and missense mutations) that are distributed throughout all exons and various deletions and insertions [1]. For a review on mutation analysis and therapy refer to Graw et al. [2]. Recently, Oldenburg et al. [3] published the distribution of different types of mutations in the F8 gene (table 1). Patients with detectable mutations in the F8 gene account for a total of $98.2 \%$ of all patients. In the remaining $1.8 \%$ of pa-

\begin{tabular}{ll}
\hline KARGER & @ 2006 S. Karger GmbH, Freiburg \\
Fax +4976145207 14 & Accessible online at: \\
$\begin{array}{l}\text { E-mail Information@Karger.de } \\
\text { www.karger.com }\end{array}$ & www.karger.com/tmh
\end{tabular}


tients, no mutations in the F8 gene were found, despite applying accurate and sensitive mutation detection methods, such as denaturing high performance liquid chromatography (DHPLC) [4] and denaturant gradient gel electrophoresis (DGGE) [5], and sequencing all exonic regions [6].

\section{HA Patients without Mutations in the F8 Gene}

Previously, a selective group of 15 out of 860 patients was screened for all types of known mutations in the F8 gene, but no changes were detected [3]. However, in a recent data compilation based on 2,350 HA patients from Germany, we identified 53 probands (so far) in whom no mutation could be identified with any of the above mentioned techniques. With 9 of these patients we have been able to carry out more detailed research. Table 2 summarizes the present knowledge regarding these patients.

Most of the studied patients share 2 important characteristics: a severe clinical phenotype (7 out of 9) and no inhibitor development. The probability of inhibitor development is known to depend on the type of mutation with a higher incidence associated with the absence of large parts of the F8 protein due to nonsense mutations, gross deletions or intron 1 and intron 22 inversions [7]. Thus, the absence of inhibitor formation in these patients implies that some trace amount of F8 is present or that at least the endogenous F8 antigen was presented to the immune system at some stage during development. This suggest that the defects in these patients may be due to either insufficient secretion or expression of the F8 protein.

In 4 of the 9 families (all with severe HA), more than one male-hemophiliac existed (table 2), thus favoring an X-linked inheritance. This assumption is strengthened by the fact that all 9 hemophiliacs were males. Five of the 9 families -2 with non-severe and 3 with severe HA - have no history of hemophilia, making them candidates for a non-X-linked mode of inheritance. None of the family trees indicated consanguinity which could have triggered autosomal recessive conditions.

Taking the above observations into consideration, one could postulate a number of explanations for the hemophilia phenotype associated with an absence of detectable mutations in the factor VIII gene:

1. Novel rearrangement (other than the intron 1 and intron 22 inversions): these could include novel inversions or duplications of one or several exons that would not alter the normal exon sequence but disrupt the normal RNA.

2. Point mutations that lie deep in the large introns (the largest being intron 22 at $32.4 \mathrm{~kb}$ ) and may affect normal mRNA splicing.

3. Defects in expression leading to very little if any F8 mRNA production.

4. Secretion defects or defects in intracellular processing that would cause F8 to remain inside the cell without being effectively secreted.
Table 1. Summary of the mutations found in 845 German HA patients

\begin{tabular}{lrc}
\hline Type of mutation & Number of mutations & Percentage, \% \\
\hline Intron 22 inversion & 302 & 35 \\
Intron 1 inversion & 8 & 1 \\
Point mutations & 402 & 46.8 \\
Small deletions & 64 & 7.5 \\
Small insertions & 23 & 2.5 \\
Large deletions & 25 & 2.9 \\
Splice-site mutations & 22 & 2.5 \\
No mutations & 15 & 1.8 \\
\hline
\end{tabular}

Table 2. Summary of clinical data of the patients without identified mutations

\begin{tabular}{llllll}
\hline Patient & Severity & $\begin{array}{l}\text { Inhibi- } \\
\text { tors }\end{array}$ & Mutation & $\begin{array}{l}\text { Familial } \\
\text { HA }\end{array}$ & $\begin{array}{l}\text { F8 } \\
\text { splicing }\end{array}$ \\
\hline 1 & severe & no & not identified & yes & normal \\
43 & severe & no & not identified & yes & normal \\
47 & severe & no & not identified & yes & normal \\
51 & severe & no & not identified & yes & normal \\
13 & severe & no & not identified & no & normal \\
16 & severe & no & not identified & no & normal \\
25 & severe & no & not identified & no & normal \\
29 & mod/mild & no & not identified & no & normal \\
44 & mild & no & not identified & no & normal \\
\hline
\end{tabular}

\section{Detailed mRNA Study}

To investigate the above hypotheses, we previously performed detailed mRNA analysis in patients available to us [8]. Detailed F8 analysis on the mRNA level would reveal the presence of rearrangements (such as inversions and duplications) that do not disrupt any of the exons themselves but rather change the relative exon positions or numbers. For example, a splicing defect that leaves out one or more exons in the mature mRNA due to an intronic mutation would be easily detected by sequencing the mRNA. A schematic diagram of the mRNA analysis is shown in figure 1.

Detailed analysis of cDNA by reverse transcriptase PCR (RTPCR) represents a powerful tool for searching causative splicing mutations or gene rearrangements. This strategy is applied with disease-related genes in patients who do not show mutations in the coding regions at the DNA level $[9,10]$. The same strategy was previously applied as the first-line mutation screening method for the F8 and F9 genes [11-13]. In fact, it was the detailed analysis of the F8 cDNA by Naylor et al. [14] that revealed a transcript interrupted in intron 22 in about $50 \%$ of severe hemophilia cases. This observation led to the discovery of a major gene rearrangement in the F8 gene - the intron 22 inversion $[15,16]$. A similar experimental strategy led to the discovery of the intron 1 inversion that occurs at a worldwide frequency of about $4 \%$ of HA cases [17, 18]. 


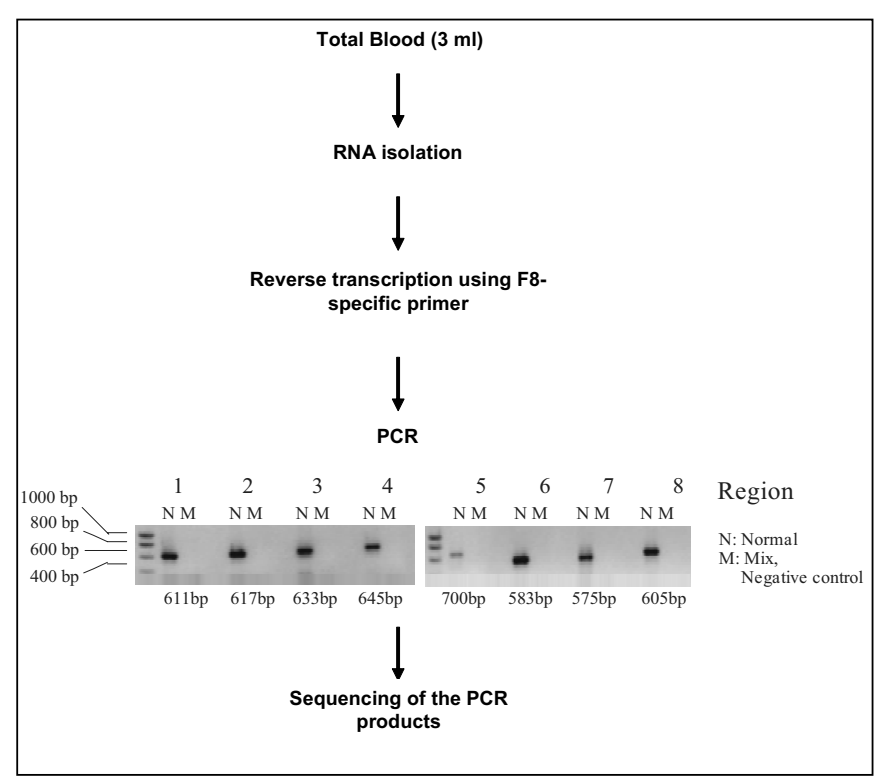

Fig. 1. Schematic diagram describing the experimental procedure for the detailed analysis of the F8 mRNA. Eight different PCR fragments covering all F8 splicing sites are generated and then sequenced and compared to normal sequences.

In the group of patients with no detectable mutations, no abnormal splicing or rearrangements of the F8 cDNA were found (table 1). This indicates that the cause for HA in these patients may indeed lie in other yet unknown regulatory regions of the F8 gene or in genes encoding interacting/modifying proteins.

One possible explanation for this observation is that there may be mutations in chaperon proteins that affect proper folding, secretion, modification and/or trafficking of the F8 protein or modulate the activity of the mature molecule in the blood. Examples of such proteins are the ERGIC-53 (also known as LMAN1) and the recently identified MCFD2 protein, which are involved in transporting both F8 and F5 from the endoplasmic reticulum (ER) to the Golgi compartment and whose defects cause a combined F5/F8 deficiency $[19,20]$. Since the F5 activity in these patients was normal (data not shown), involvement of these 2 particular proteins could be excluded. However, other as yet unknown proteins could be involved in $\mathrm{F} 8$ protein processing. For example, the secretion efficacy of the F8 molecule depends on correct processing of the protein in the ER-Golgi apparatus, which includes processes such as phosphorylation, sulfatation, glycosylation and proteolytic cleavage in the B domain at aa 1313 and 1648 by a yet unknown protein. Given that the B domain of the F8 is a target for $19 \mathrm{~N}$-glycosylation sites and $3 \mathrm{O}$-glycosylation sites and taking into consideration the proposed role of this domain in the intracellular trafficking of F8 molecules, the involvement of glycosylation defects in the hemophilic phenotype is not unlikely.
Another possible explanation for the hemophilic phenotype is a diminished expression/secretion of the F8 mRNA/mature protein, which would lead to lower amounts of active F8 protein in circulation. In fact, 1 patient showed direct evidence of the absence of detectable F8 mRNA [21]. The reduced mRNA expression could be explained by defects in regulatory elements, such as enhancers or other epigenetics factors. However, with F8, little is known about such factors. Some unexplained silencing of expression has also been observed in other diseases, such as von Willebrand disease (VWD; $w w w . s h e f f i e l d . a c . u k / v w f /)$. VWD is a recessive disease that is usually caused by 2 mutations on both alleles of the von Willebrand factor (VWF) gene. However, a number of cases have been reported in which one allele harbored a mutation while the other allele is not expressed [22-24]. Congenital hypothyroidism is another recessive disease caused by mutations in the gene coding thyroid peroxidase (TPO). Patients suffering from this disease are usually homozygous or compound heterozygous for gene mutations. In about $17 \%$ of cases, there is only one mutated allele. In one of these cases, Fugazzola et al. [25] showed that on the DNA level the intact allele is unexpressed and on the RNA level it is undetectable. In all above cases, the exact molecular mechanisms leading to absent or decreased expression are yet unknown.

\section{Future Direction}

For further identification of the mutations in these HA cases, the following directions could be followed. Firstly, a quantitative RT-PCR approach is required to investigate whether these patients exhibit lower expression levels compared to healthy individuals. Secondly, an international consortium study is needed to assemble all familial HA cases with unidentified mutations and conduct a genome-wide linkage analysis to identify the defective locus (or loci). The phenotypic data of these patients will be completed with respect to the inhibitor status, potentially revealing a complete lack of endogenous F8 synthesis and thus indicating a severe molecular defect. Pedigree data will be gathered to identify patients with either sporadic or familial HA. Data on related female carriers will be included to increase the number of informative individuals. In families with familial HA (more than one hemophiliac or one hemophiliac plus at least one supposed carrier), F8 gene polymorphism will be analyzed to investigate whether the defect is segregating with the F8 gene. In families in which the phenotype does not segregate with the F8 gene, a complete genome linkage analysis will be carried out to identify chromosomal regions of interest that may harbor candidate genes that could potentially play a role in the pathogenesis of HA. Regions with significantly increased lod scores will be mapped in more detail to narrow down the candidate intervals. Genes within these intervals will be arranged according to function and size. Promising candidates will be sequenced to screen for mutations. 


\section{Conclusions}

In a minority of HA patients, the molecular defect is not located in any of the genes known to be involved in the F8 pathway. Detailed RNA analysis in a group of these patients revealed normal F8 mRNA. Thus, we can exclude major rearrangements, such novel inversions or duplications, that could disrupt the mRNA. Major efforts are still needed to identify the loci responsible for the HA phenotype in these patients.

\section{Acknowledgments}

We would like to thank Prof. Peter Hanfland for his guidance and support in many scientific projects throughout his time as director of the Institute of Experimental Hematology and Transfusions Medicine (Bonn, Germany). This work was supported by research grants from the German Human Genome Project (BMBF/DLR 01KW0305).

\section{References}

1 Kemball-Cook G, Tuddenham EG, Wacey AI: The factor VIII structure and mutation resource site: HAMSTeRS version 4. Nucleic Acids Res 1998;26 (1):216-219.

2 Graw J, Brackmann HH, Oldenburg J, Schneppenheim R, Spannagl M, Schwaab R: Haemophilia A from mutation analysis to new therapies. Nat Rev Genet 200;6(6):488-501.

3 Oldenburg J, Ananyeva NM, Saenko EL. Molecular basis of haemophilia A. Haemophilia 2004;10: 133-139.

4 Oldenburg J, Ivaskevicius V, Rost S, Fregin A, White K, Holinski-Feder E, Muller CR, Weber BH: Evaluation of DHPLC in the analysis of hemophilia A. J Biochem Biophys Methods 2001;47(1-2): $39-51$.

$>5$ Higuchi M, Antonarakis SE, Kasch L, Oldenburg J, Economou-Petersen E, Olek K, Arai M, Inaba H, Kazazian HH Jr: Molecular characterization of mild-to-moderate hemophilia A: detection of the mutation in 25 of 29 patients by denaturing gradient gel electrophoresis. Proc Natl Acad Sci U S A 1991;88(19):8307-8311.

6 Klopp N, Oldenburg J, Uen C, Schneppenheim R, Graw J: 11 hemophilia A patients without mutations in the factor VIII encoding gene. Thromb Haemost 2002;88(2):357-360.

7 Oldenburg J, El-Maarri O, Schwaab R: Inhibitor development in correlation to factor VIII genotypes. Haemophilia 2002;8:23-29.

8 Thomson SA, Wallace MR: RT-PCR splicing analysis of the NF1 open reading frame. Hum Genet 2002;110(5):495-502.

$>$ El-Maarri O, Herbiniaux U, Graw J, Schroder J, Terzic A, Watzka M, Brackmann HH, Schramm W, Hanfland P, Schwaab R, Muller CR, Oldenburg J: Analysis of mRNA in hemophilia A patients with undetectable mutations reveals normal splicing in the factor VIII gene. J Thromb Haemost 2005;3(2): 332-339.
10 Lai LW, Whitehair O, Wu MJ, O'Meara M, Lien YH: Analysis of splice-site mutations of the alphagalactosidase A gene in Fabry disease. Clin Genet 2003;63(6):476-482.

11 Maugard C, Tuffery S, Aguilar-Martinez P, Schved JF, Gris JC, Demaille J, Claustres M: Protein truncation test: detection of severe haemophilia a mutation and analysis of factor VIII transcripts. Hum Mutat 1998;11(1):18-22.

12 Bidichandani SI, Lanzon WG, Shiach CR, Lowe GD, Connor JM: Detection of mutations in ectopic factor VIII transcripts from nine haemophilia A patients and the correlation with phenotype. Hum Genet 1995;95(5):531-8.

13 Ketterling RP, Drost JB, Scaringe WA, Liao DZ, Liu JZ, Kasper CK, Sommer SS: Reported in vivo splice-site mutations in the factor IX gene: severity of splicing defects and a hypothesis for predicting deleterious splice donor mutations. Hum Mutat 1999;13(3):221-231.

14 Naylor JA, Green PM, Rizza CR, Giannelli F: Factor VIII gene explains all cases of haemophilia A. Lancet 1992:340:1066-1067.

15 Lakich D, Kazazian Jr HH, Antonarakis SE, Gitschier J: Inversions disrupting the factor VIII gene are a common cause of severe haemophilia A. Nat Genet 1993;5:236-241.

16 Naylor J, Brinke A, Hassock S, Green PM, Giannelli F: Characteristic mRNA abnormality found in half the patients with severe haemophilia A is due to large DNA inversions. Hum Mol Genet 1993;2: 1773-1778.

17 Brinke A, Tagliavacca L, Naylor J, Green P, Giangrande P, Giannelli F: Two chimaeric transcription units result from an inversion breaking intron 1 of the factor VIII gene and a region reportedly affected by reciprocal translocations in T-cell leukaemia. Hum Mol Genet 1996;5:1945-1951.

18 Bagnall RD, Waseem N, Green PM, Giannelli F: Recurrent inversion breaking intron 1 of the factor VIII gene is a frequent cause of severe haemophilia A. Blood 2002;99(1):168-174.
19 Nichols WC, Seligsohn U, Zivelin A, Terry VH, Hertel CE, Wheatley MA, Moussalli MJ, Hauri HP, Ciavarella N, Kaufman RJ, Ginsburg D: Mutations in the ER-Golgi intermediate compartment protein ERGIC-53 cause combined deficiency of coagulation factors V and VIII. Cell 1998;93(1):61-70.

20 Zhang B, Cunningham MA, Nichols WC, Bernat JA, Seligsohn U, Pipe SW, McVey JH, SchulteOverberg U, de Bosch NB, Ruiz-Saez A, White GC, Tuddenham EG, Kaufman RJ, Ginsburg D Bleeding due to disruption of a cargo-specific ERto-Golgi transport complex. Nat Genet 2003;34(2): 220-225.

21 El-Maarri O, Singer H, Klein C, Brackmann HH, Schröder J, Graw J, Müller CR, Schramm W, Schwaab R, Hanfland P, Haaf T, Oldenburg J: Lack of factor VIII mRNA: a novel mechanism leading to hemophilia A. Blood 2006; (in press).

22 Peerlinck K, Eikenboom JC, Ploos Van Amstel HK, Sangtawesin W, Arnout J, Reitsma PH, Vermylen J, Briet E: A patient with von Willebrand's disease characterized by a compound heterozygosity for a substitution of Arg854 by Gln in the putative factor-VIII-binding domain of von Willebrand factor (vWF) on one allele and very low levels of mRNA from the second vWF allele. Br J Haematol 1992;80(3):358-363.

23 Eikenboom JC, Reitsma PH, Peerlinck KM, Briet E: Recessive inheritance of von Willebrand's disease type I. Lancet 1993;341(8851):982-986.

24 Gu J, Jorieux S, Lavergne JM, Ruan C, Mazurier C, Meyer D: A patient with type $2 \mathrm{~N}$ von Willebrand disease is heterozygous for a new mutation: Gly22Glu. Demonstration of a defective expression of the second allele by the use of monoclonal antibodies. Blood 1997;89(9):3263-3269.

25 Fugazzola L, Cerutti N, Mannavola D, Vannucchi G, Fallini C, Persani L, Beck-Peccoz P: Monoallelic expression of mutant thyroid peroxidase allele causing total iodide organification defect. J Clin Endocrinol Metable 2003;88(7):3264-3271. 